\title{
Article \\ Adherence to COVID-19 Preventive Measures in Mozambique: Two Consecutive Online Surveys
}

\author{
António Júnior ${ }^{1, *}$, Janeth Dula ${ }^{1}$, Sérgio Mahumane ${ }^{1}{ }^{\circledR}$, Olivier Koole ${ }^{2}{ }^{\circledR}$, Sónia Enosse ${ }^{1}$, \\ Joseph Nelson Siewe Fodjo ${ }^{3}(1)$ and Robert Colebunders ${ }^{3}$ (D) \\ 1 Direcção de Pesquisa em Saúde e Bem-Estar, Instituto Nacional de Saúde, Maputo 1120, Mozambique; \\ janet.dula@ins.gov.mz (J.D.); sergio.mahumane@ins.gov.mz (S.M.); sonia.enosse@ins.gov.mz (S.E.) \\ 2 International Center for AIDS Care and Treatment Programs (ICAP) at Columbia University, \\ Maputo 1101, Mozambique; ok2297@cumc.columbia.edu \\ 3 Global Health Institute, University of Antwerp, 2000 Antwerp, Belgium; \\ JosephNelson.SieweFodjo@uantwerpen.be (J.N.S.F.); Robert.colebunders@uantwerpen.be (R.C.) \\ * Correspondence: antonio.junior@ins.gov.mz; Tel.: +258-87-386-1820
}

check for updates

Citation: Júnior, A.; Dula, J.; Mahumane, S.; Koole, O.; Enosse, S.; Fodjo, J.N.S.; Colebunders, R. Adherence to COVID-19 Preventive Measures in Mozambique: Two Consecutive Online Surveys. Int. J. Environ. Res. Public Health 2021, 18, 1091. https://doi.org/10.3390/ ijerph18031091

Received: 11 December 2020 Accepted: 23 December 2020 Published: 26 January 2021

Publisher's Note: MDPI stays neutral with regard to jurisdictional clai$\mathrm{ms}$ in published maps and institutional affiliations.

Copyright: (C) 2020 by the authors. Licensee MDPI, Basel, Switzerland. This article is an open access article distributed under the terms and conditions of the Creative Commons Attribution (CC BY) license (https:// creativecommons.org/licenses/by/ $4.0 /)$.

\begin{abstract}
We assessed adherence to government recommendations implemented shortly after the introduction of COVID-19 in Mozambique in March 2020, through two online cross-sectional surveys in April and June 2020. We quantified adherence to preventive measures by a composite score comprising of five measures: physical distancing, face mask use, hand hygiene, cough hygiene, and avoidance of touching the face. 3770 and 1115 persons participated in the first and second round respectively. Wearing face masks, regular handwashing and cough hygiene all reached compliance rates of over $90 \%$ while physical distancing and avoiding to touch the face reached a compliance rate of $80-90 \%$. A multivariable model investigating factors associated with adherence found that being older, more educated, and belonging to the healthcare sector increased the odds for higher adherence. Private workers and retired people, respondents receiving COVID-19 information through social media, and those who reported flu-like symptoms were less likely to adhere. $6 \%$ of respondents reported flu-like symptoms which aligned with the WHO clinical definition of COVID19 , suggesting low level community transmission. In conclusion, most respondents in this online survey in Mozambique complied well with strategies to prevent COVID-19. Whether the good preventive behaviour explains the low grade COVID-19 transmission requires further study.
\end{abstract}

Keywords: COVID-19; Mozambique; preventive measures; adherence; survey

\section{Introduction}

On 11 March 2020 COVID-19 was declared a global pandemic by the World Health Organization (WHO, Geneva, Switzerland) [1]. In order to limit transmission, the WHO recommends minimizing contact between infected and non-infected persons, early detection and isolation of cases, and general personal and collective hygiene measures [2]. As part of these measures, the use of face masks, hand washing, physical distancing, cough etiquette and avoidance of crowded places persons are recommended.

The first COVID-19 case in Mozambique was detected on 22 March 2020, and one week later on 30 March, the President of Mozambique declared the State of Emergency, level 3 (with levels ranging from 1 to 4 , and 4 being the most stringent level of social distancing) [3]. The order included closure of schools, restaurants and bars, churches and sports facilities, restricted gatherings to 10 people or less, restricted the number of people at the workplace, and restrictions on public transport and restrictions on movement. This state of emergency has been extended monthly (on 29 April, 28 May and 26 June) and was maintained up to 6 September 2020 [4].

By 29 November 2020, more than 15,000 confirmed COVID-19 cases had been diagnosed in Mozambique [5]. Maputo City is the epicenter of the COVID-19 epidemic in the 
country with about half of the diagnosed cases residing there; next comes Maputo Province accounting for about $17 \%$ of the diagnosed cases [5]. An earlier sero-prevalence survey showed a community prevalence of $\sim 4 \%$ in Maputo City [6].

It is currently unclear how well people adhere to these measures over time and which factors determine adherence. We conducted this online survey to assess how well people in Mozambique respect the COVID-19 preventive strategies including social distancing, staying at home, and personal and collective hygiene measures, and assessed the factors associated with reduced adherence.

\section{Methods}

\subsection{Study Setting and Design}

We conducted two consecutive cross-sectional surveys in Mozambique (Figure 1): the first from 11 to 17 May and the second one from 9 to 22 June. This study was part of a network of online surveys organized by the International Citizen Project COVID-19 (ICPCovid; online platform available at: https://www.icpcovid.com/en/home) which uses web-based surveys to investigate the impact of COVID-19 and associated restrictions on residents of several low and middle-income countries. An international questionnaire to investigate the impact of COVID-19 and associated restrictions on residents of low and middle-income countries was developed by a team of twenty international ICPcovid consortium members, and has already been administered in several African countries as Uganda [7], the Democratic Republic of Congo [7], Somalia [8] and Nigeria [9]. This questionnaire was adapted by the research team in Mozambique and translated to Portuguese. We used a snowball approach for sharing the questionnaire through email and other social networks (like WhatsApp) while asking participants to further distribute the questionnaire with their contacts.

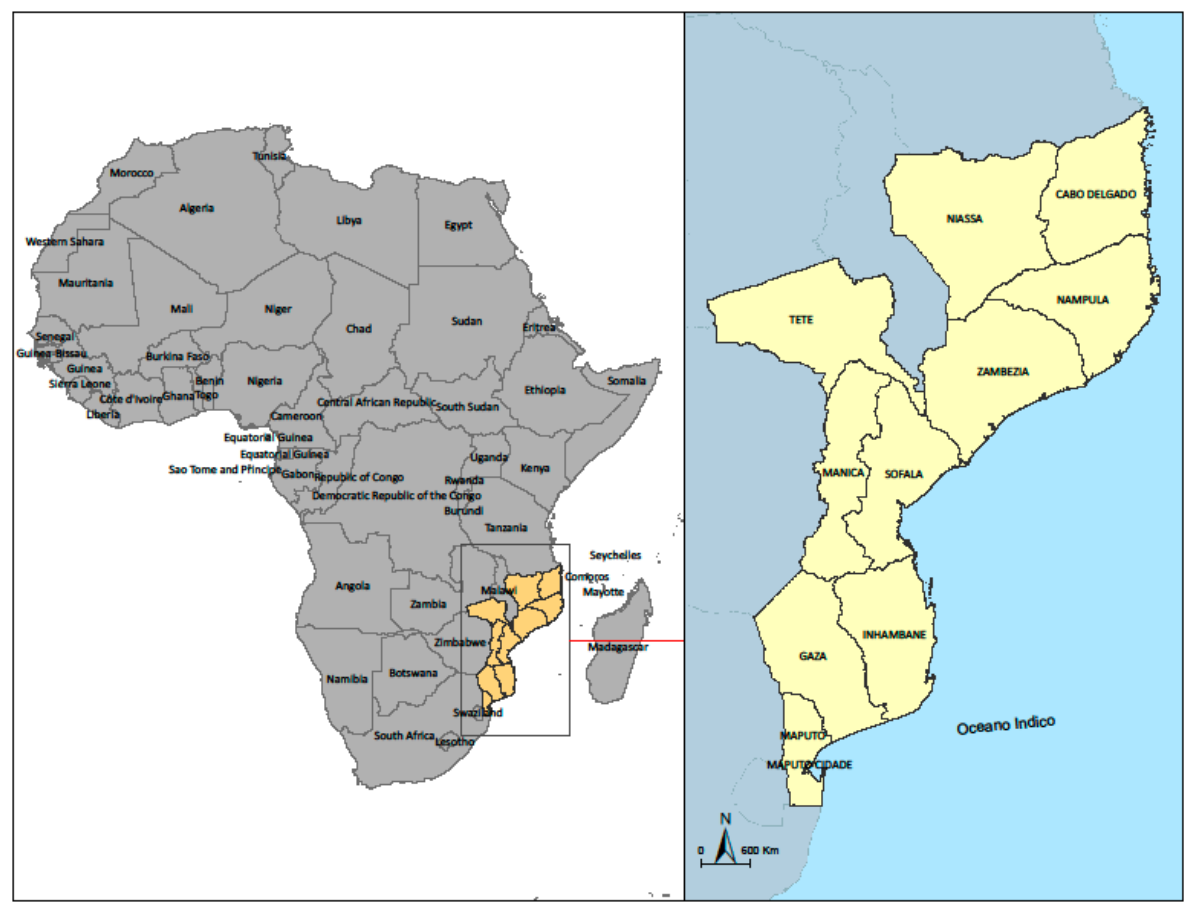

Figure 1. Map of Mozambique with its provinces.

\subsection{Data Collection}

Using the online tool, we asked participants of 18 years and older for informed consent prior to data collection. We collected sociodemographic data, data on adherence to preventive measures like social distancing, staying at home, and personal and collective hygiene measures, and data on flu-like symptoms and having been tested for COVID-19. 
Five-level Likert scores were used to assess fear or worry for oneself or others during the COVID-19 outbreak, and difficulties to adhere to the stay-at-home instructions; scores ranged from 1 (least level of fear/worry or difficulty) to 5 (highest level). All responses were submitted anonymously to the ICPcovid platform where they were stored in a password protected server in Belgium until data extraction.

\subsection{Data Analysis}

Descriptive statistics are presented using means with standard deviation (SD) for continuous outcomes, and percentages (\%) for categorical variables. We used Pearson's Chisquared test to compare proportions across surveys and to investigate associations between two categorical variables. We used the Mann Whitney $U$ test to compare continuous variables. The level of adherence to COVID-19 preventive measures was quantified by means of a composite score based on the responses to five questions (Table 1). An ordinal logistic regression model was constructed to investigate factors associated with adherence using the composite score as the dependent variable.

Table 1. Composition of the adherence score to COVID-19 preventive measures.

\begin{tabular}{cllc}
\hline Variable & Scoring & Interpretation \\
\hline $\begin{array}{c}\text { I follow the 1.5-2 m physical } \\
\text { distance rule }\end{array}$ & Yes & 1 & \multirow{2}{*}{ 1 point for yes, 0 point for no } \\
\hline No & Yes & 1 & 1 point for yes, 0 point for no \\
go out & No & 0 & If any (or both) questions have \\
go mask when I & Yes & 1 & answer yes, give just 1 point \\
\hline I wash hands regularly OR & No & 0 & 1 point for yes, 0 point for no \\
I use hand sanitizer & Yes & 1 & \multirow{2}{*}{ 1 point for yes, 0 point for no } \\
When I cough/sneeze, I & No & 0 & \\
\hline I avoid touching my face & Yes & 1 &
\end{tabular}

Total adherence score (maximum): 5 .

\subsection{Ethical Considerations}

The study protocol was approved by the Institutional Bioethics Committee of the National Institute of Health of Mozambique (Ref: 029/CIBS-INS/2020) and the University of Antwerp Ethics Committee.

\section{Results}

\subsection{Participant Characteristics}

We included 3770 and 1115 participants in the first and second round respectively (Table 2). About half of the participants came from an urban setting, $\sim 35 \%$ from a sub-urban setting and $\sim 15 \%$ from a rural setting. In the first and second survey, most respondents were male $(57.7 \%$ and $58.6 \%$ respectively), had an undergraduate university level degree $(68.9 \%$ and $70.5 \%$ respectively) and were government employees (33.4\% and $46.1 \%$ respectively). More than half of the respondents worked from home on the day of the first and second survey (59.8\% and 57.3\% respectively). A small percentage were smokers (5.4\% and $4.0 \%$ respectively) and had some chronic illness ( $21.4 \%$ and $20.5 \%$ respectively). 
Table 2. Participants' characteristics during the two surveys in Mozambique.

\begin{tabular}{|c|c|c|c|}
\hline Characteristics & $\begin{array}{l}\text { Survey } 1 \text { Participants } \\
n=3770\end{array}$ & $\begin{array}{l}\text { Survey } 2 \text { Participants } \\
\text { n = } 1115\end{array}$ & $p$-Value * \\
\hline Age: Mean (SD) & $34.7(10.6)$ & $33.6(9.2)$ & $<0.001$ \\
\hline \multicolumn{4}{|l|}{ Gender: n (\%) } \\
\hline Male & $2174(57.7 \%)$ & $674(58.6 \%)$ & \multirow{2}{*}{0.594} \\
\hline Female & $1596(42.3 \%)$ & $476(41.4 \%)$ & \\
\hline \multicolumn{4}{|l|}{ Education level: n (\%) } \\
\hline Primary school & $17(0.5 \%)$ & $6(0.5 \%)$ & \multirow{4}{*}{0.704} \\
\hline Secondary school & $1151(30.5 \%)$ & $332(28.9 \%)$ & \\
\hline University: Undergraduate & $2596(68.9 \%)$ & $811(70.5 \%)$ & \\
\hline University: Postgraduate & $6(0.2 \%)$ & $1(0.1 \%)$ & \\
\hline \multicolumn{4}{|l|}{ Residential setting: n (\%) } \\
\hline Rural & $549(14.6 \%)$ & $187(16.3 \%)$ & \multirow{3}{*}{0.090} \\
\hline Sub-Urban & $1353(35.9 \%)$ & $434(37.7 \%)$ & \\
\hline Urban & $1868(49.5 \%)$ & $529(46.0 \%)$ & \\
\hline Live alone in household: $\mathrm{n}(\%)$ & $267(7.1 \%)$ & $88(7.7 \%)$ & 0.556 \\
\hline \multicolumn{4}{|l|}{ Profession: n (\%) } \\
\hline Private employee & $1554(41.2 \%)$ & $355(30.9 \%)$ & \multirow{6}{*}{$<0.001$} \\
\hline Government employee & $1261(33.4 \%)$ & $530(46.1 \%)$ & \\
\hline Student & $497(13.2 \%)$ & $165(14.3 \%)$ & \\
\hline Unemployed & $298(7.9 \%)$ & $70(6.1 \%)$ & \\
\hline Other & $105(2.8 \%)$ & $22(1.9 \%)$ & \\
\hline Retired & $55(1.5 \%)$ & $8(0.7 \%)$ & \\
\hline Working from home: $\mathrm{n}(\%)^{\mathrm{a}}$ & $2043(59.8 \%)$ & $607(57.3 \%)$ & 0.166 \\
\hline Healthcare sector worker: $\mathrm{n}(\%)$ & $910(24.1 \%)$ & $446(38.8 \%)$ & $<0.001$ \\
\hline \multicolumn{4}{|l|}{ Source of COVID-19 information: $\mathrm{n}(\%)$} \\
\hline Social Media & $453(12.0 \%)$ & $655(57.0 \%)$ & $<0.001$ \\
\hline Smoking: n (\%) & $205(5.4 \%)$ & $46(4.0 \%)$ & 0.062 \\
\hline Presence of flu symptoms & $660(17.5 \%)$ & $212(18.4 \%)$ & 0.498 \\
\hline Underlying chronic disease: $\mathrm{n}(\%) \mathrm{b}$ & $805(21.4 \%)$ & $236(20.5 \%)$ & 0.574 \\
\hline Tested for COVID-19: n (\%) & NA & $69(6.0 \%)$ & NA \\
\hline Positive COVID-19 test: n (\%) & NA & $0(0.0 \%)$ & NA \\
\hline $\begin{array}{l}\text { Meet WHO clinical definition of } \\
\text { suspected COVID-19 [7]: } \mathrm{n}(\%)\end{array}$ & $239(6.3 \%)$ & $76(6.6 \%)$ & 0.797 \\
\hline
\end{tabular}

NA: Not Applicable. ${ }^{*}$ Chi squared test for categorical variables, Mann-Whitney U test for continuous variables. ${ }^{a}$ Applicable only to workers. ${ }^{b}$ Heart disease, diabetes, hypertension, cancer, HIV, or asthma.

Overall, about $18 \%$ of respondents in both surveys reported experiencing at least one flu-like symptoms during the two weeks preceding the survey $(17.5 \%$ during the first survey, and $18.4 \%$ during the second survey; $p=0.498)$. The proportion of participants meeting the WHO clinical definition of COVID-19 [10] was similar in both survey rounds (Table 2). Of the 69 respondents who reported to have been tested for COVID-19 during the second round, none was infected with the virus.

\subsection{COVID-19 Preventive Behaviours}

Wearing face masks, regular handwashing and cough hygiene all reached compliance rates of over $90 \%$, physical distancing and avoiding to touch the face reached a compliance rate of $80-90 \%$, and the regular use of alcohol-based gel was reported for about $65 \%$ of respondents (Table 3 ). 
Table 3. COVID-19 preventive behaviours.

\begin{tabular}{|c|c|c|c|}
\hline COVID-19 Preventive Behaviours & $\begin{array}{l}\text { Survey } 1 \\
\mathrm{n}=3770\end{array}$ & $\begin{array}{l}\text { Survey } 2 \\
\mathrm{n}=1115\end{array}$ & $p$-Value * \\
\hline \multicolumn{4}{|l|}{ Individual measures } \\
\hline Wear face masks: n (\%) & $3541(93.9 \%)$ & $1110(96.5 \%)$ & 0.001 \\
\hline Observe 1.5 m physical distancing: $\mathrm{n}(\%)$ & $3270(86.7 \%)$ & $945(82.2 \%)$ & $<0.001$ \\
\hline Regular handwashing: n (\%) & $3636(96.4 \%)$ & $1097(95.4 \%)$ & 0.121 \\
\hline Regular use of alcohol-based gel: $\mathrm{n}(\%)$ & $2551(67.7 \%)$ & $769(66.9 \%)$ & 0.639 \\
\hline Cover mouth after coughing/sneezing: n (\%) & $3640(96.6 \%)$ & $1114(96.9 \%)$ & 0.668 \\
\hline Avoid to touch face (eyes, nose, mouth): n (\%) & $3094(82.1 \%)$ & $946(82.3 \%)$ & 0.917 \\
\hline \multicolumn{4}{|l|}{ Adherence score: $\mathrm{n}(\%)$} \\
\hline 0 & $3(0.1 \%)$ & $0(0.0 \%)$ & \multirow{6}{*}{0.042} \\
\hline 1 & $13(0.3 \%)$ & $0(0.0 \%)$ & \\
\hline 2 & $53(1.4 \%)$ & $12(1.0 \%)$ & \\
\hline 3 & $246(6.5 \%)$ & $97(8.4 \%)$ & \\
\hline 4 & $864(22.9 \%)$ & $276(24.0 \%)$ & \\
\hline 5 & $2591(68.7 \%)$ & $765(66.5 \%)$ & \\
\hline Been to a bar/restaurant in the past 7 days: $\mathrm{n}(\%)$ & $264(7.0 \%)$ & $108(9.4 \%)$ & 0.009 \\
\hline Been to a market in the past 7 days: $n(\%)$ & $2197(58.3 \%)$ & $736(64.0 \%)$ & 0.001 \\
\hline Been to a religious gathering in the past 7 days: $n(\%)$ & $80(2.1 \%)$ & $25(2.2 \%)$ & 1.000 \\
\hline Meeting with more than 10 persons: $\mathrm{n}(\%)$ & $559(14.8 \%)$ & $248(21.6 \%)$ & $<0.001$ \\
\hline Travelled during the past 7 days: $\mathrm{n}(\%)$ & $552(14.6 \%)$ & $194(16.9 \%)$ & 0.072 \\
\hline
\end{tabular}

\footnotetext{
${ }^{*}$ Chi squared test.
}

The mean adherence score of participants was similar during both surveys: $4.6 \pm 0.7$ (on a scale of 1 to 5). Upon combining data from the two surveys and investigating mean adherence scores by region, we found significant disparities $(p=0.001)$ with the highest adherence reported in the Gaza region, and the lowest adherence reported in Sofala (Table 4).

Table 4. Mean adherence scores by region in Mozambique during the study period.

\begin{tabular}{ccc}
\hline Region & Number of Respondents, n (\%) & Adherence Score, Mean (SD) \\
\hline Cabo Delgado & $98(2.0 \%)$ & $4.50(0.74)$ \\
Gaza & $333(6.8 \%)$ & $4.65(0.68)$ \\
Inhambane & $286(5.8 \%)$ & $4.62(0.63)$ \\
Manica & $140(2.8 \%)$ & $4.54(0.78)$ \\
Maputo City & $1331(27.0 \%)$ & $4.57(0.69)$ \\
Maputo Province & $1401(28.5 \%)$ & $4.61(0.69)$ \\
Nampula & $291(5.9 \%)$ & $4.49(0.80)$ \\
Niassa & $175(3.6 \%)$ & $4.62(0.73)$ \\
Sofala & $468(9.5 \%)$ & $4.47(0.78)$ \\
Tete & $170(3.5 \%)$ & $4.61(0.73)$ \\
Zambezia & $227(4.6 \%)$ & $4.60(0.71)$ \\
\hline
\end{tabular}

\subsection{Analysis of Likert Scores}

The mean level of worry/fear about respondents' own health during the COVID-19 outbreak increased slightly from $2.7 \pm 1.3$ during the first survey to $2.8 \pm 1.3$ during the second survey $(p=0.021)$. Difficulty to stay at home remained stable during both surveys $(3.1 \pm 1.28$ and $3.1 \pm 1.29 ; p=0.345)$. However, we found that it was more difficult to stay at home for men $(p<0.001)$ but found no difference in difficulty scores across residential setting (rural vs. sub-urban vs. urban; $p=0.110$ ). 


\subsection{Factors Associated with Adherence to COVID-19 Preventive Measures}

A multivariable model investigating factors associated with the adherence score to COVID-19 preventive measures found that being older, having attained secondary or undergraduate education levels, and belonging to the healthcare sector (as student or worker) increased the odds for higher adherence (Table 5). Private workers, retired people, those who received COVID-19 information from social media, and those who reported flu-like symptoms were less likely to adhere to the preventive measures.

Table 5. Ordinal logistic regression model for Adherence score.

\begin{tabular}{|c|c|c|}
\hline Covariate & Adjusted OR (95\% CI) & $p$-Value \\
\hline Age & $1.03(1.02-1.04)$ & $<0.001$ \\
\hline Male gender & $1.04(0.92-1.18)$ & 0.551 \\
\hline \multicolumn{3}{|l|}{ Profession } \\
\hline Government employee & Ref & \\
\hline Private employee & $0.86(0.74-0.99)$ & 0.041 \\
\hline Student & $0.90(0.72-1.11)$ & 0.326 \\
\hline Other & $0.97(0.65-1.46)$ & 0.872 \\
\hline Unemployed & $1.09(0.84-1.41)$ & 0.532 \\
\hline Retired & $0.43(0.24-0.78)$ & 0.004 \\
\hline \multicolumn{3}{|l|}{ Residential setting } \\
\hline Rural & Ref & \\
\hline Sub-urban & $0.99(0.82-1.20)$ & 0.937 \\
\hline Urban & $1.03(0.86-1.23)$ & 0.772 \\
\hline \multicolumn{3}{|l|}{ Educational level } \\
\hline Primary & Ref & \\
\hline Secondary & $3.25(1.38-7.52)$ & 0.006 \\
\hline Undergraduate & $2.93(1.24-6.78)$ & 0.012 \\
\hline Postgraduate & $4.26(0.77-33.81)$ & 0.117 \\
\hline Healthcare sector worker & $1.17(1.01-1.36)$ & 0.032 \\
\hline Living alone in household & $0.90(0.72-1.14)$ & 0.369 \\
\hline Presence of flu symptoms & $0.64(0.55-0.74)$ & $<0.001$ \\
\hline COVID-19 information from social media & $0.72(0.61-0.84)$ & $<0.001$ \\
\hline \multicolumn{3}{|l|}{ Survey round } \\
\hline Round 1 & Ref & \\
\hline Round 2 & $1.04(0.89-1.23)$ & 0.599 \\
\hline
\end{tabular}

OR: Odds ratio; CI: Confidence interval; Ref: Reference category.

\section{Discussion}

Our data show that most people in Mozambique who participated in the two surveys complied well with most strategies to prevent COVID-19 transmission. In particular, face mask use and regular hand washing were reported by more than $90 \%$ of the respondents. This high compliance with face mask use is in contrast with certain other African countries where face mask use is reported to be low (using similar research studies as the present study), such as in Uganda (32.7\%) [7], Democratic Republic of Congo (43.2\%) [7], Somalia (51.2\%) [8] and Nigeria (64.5\%) [9]. Few people reported to have been to a bar/restaurant or to have attended a religious gathering during the last seven days but more than half of the respondents had been to a market. As it is difficult to respect physical distance at markets, wearing face-masks should particularly be recommended at these places.

During both surveys a relatively large number of respondents $(18 \%)$ reported experiencing at least one flu-like symptoms during the two weeks preceding the survey. In about $6 \%$ of all respondents, the flu symptoms met the criteria of the WHO clinical definition of 
suspected COVID-19 infection. However, all 69 participants (54 without a recent flu-like illness) with available COVID-19 results tested negative. This suggest low grade COVID-19 transmission in Mozambique during the period of the surveys. This has been confirmed by several provincial sero-surveys in Mozambique with community sero-prevalences ranging from less than $1 \%$ [11] to $5 \%$ [12].

Persons with low adherence were more likely to report a flu-like illness. This was contrary to our expectations; we anticipated that during a COVID-19 outbreak, the experience of flu-like symptoms would cause people to be more careful with their health and consequently improve their adherence to COVID-19 preventive measures. However, a more likely interpretation of this finding is that the flu-like symptoms were the consequences of low adherence to preventive measures.

Research has shown that face masks are an important tool to prevent the spread of respiratory pathogens [13]. However, the evidence that face masks also may protect a person from acquiring a respiratory infection is less well established [14].

A higher level of education, with the exception of postgraduate education level (only 7 respondents), was associated with better preventive behaviours. Participants who received COVID-19 information from social media were less likely to be adherent with the preventive measures suggesting that social media may have had a negative effect on the preventive behaviour of people. Therefore, it is important that governments disseminate clear, evidence based messages to the public about COVID-19 preventive measures. Being older was also related to high adherence to preventive measures. This is an important finding as older age is a risk factor for severe COVID-19 disease, and therefore the protection of the elderly is a priority during the current outbreak.

Despite the fact that most COVID-19 infection are reported from Maputo City, adherence with the COVID-19 preventive measures was relatively high in this province. The explanation for this may be that in this province which was the epicenter of the local outbreak, people considered themselves more at risk for COVID-19 infection and therefore may be more motivated to adhere to the preventive measures.

Some limitations of the study should be mentioned. To keep the questionnaire short and easier to fill, we assessed adherence to preventive measures using yes/no questions. Using Likert-like scale questions would have provided more precise information, albeit making the questionnaire lengthier. Similarly, the use of the term "regular" in quantifying the frequency of handwashing was not very precise and could be interpreted differently by different respondents. Moreover, self-reported responses may not reflect the real-life behaviour of participants.

People with no or limited internet access (less educated persons and those belonging to the lower social classes) were not able to participate in the research. People without internet connection generally will be older and are less educated but also may have been less exposed about fake news circulating on the internet. Therefore, our respondents cannot be considered as representative of the general population in Mozambique. As this was a cross-sectional survey, causality is difficult to assess, as we pointed out above when assessing the relationship between adhering to preventive measures and having flu-like symptoms.

\section{Conclusions}

In conclusion, these online surveys in Mozambique showed that most respondents complied well with most strategies to prevent COVID-19 transmission. In particular, adherence to face mask use and regular hand washing was high (more than 90\%). However, a considerable number of participants attended markets where physical distancing can be challenging, which can be a risk factor for contracting COVID-19. Based on reported symptoms and data from local sero-surveys, there seems to have been low grade community COVID-19 transmission during the period of the surveys. Whether good COVID-19 preventive behaviour in Mozambique is responsible for this low grade of COVID-19 transmission requires further study. Complementing our study findings with qualitative research partic- 
ularly among populations at higher risk for COVID-19 infection would certainly provide a better picture of the COVID-19 behavioural landscape in the country.

Author Contributions: Conceptualization, R.C. and A.J.; methodology, J.N.S.F.; software, J.N.S.F.; validation, O.K., J.N.S.F. and J.D.; formal analysis, J.N.S.F.; investigation, J.D., A.J. and S.M.; resources, R.C.; data curation, J.N.S.F.; writing — original draft preparation, O.K.; writing—review and editing, O.K., S.M., S.E. and A.J.; visualization, A.J.; supervision, R.C.; project administration, R.C.; funding acquisition, R.C. All authors have read and agreed to the published version of the manuscript.

Funding: R. Colebunders received VLIRUOS (Flemish university development aid) funding to establish the ICPcovid website used to organize the survey.

Institutional Review Board Statement: The study was conducted according to the guidelines of the Declaration of Helsinki, and approved by the Ethics Committee of the National Institute of Health of Mozambique (Ref:029/CIBS-INS/2020; 28/04/2020) and the Ethics Committee of the University of Antwerp (Ref:20/13/148; 23/03/2020).

Informed Consent Statement: Informed consent was obtained from all subjects involved in the study.

Data Availability Statement: The data are available upon reasonable request through the ICPcovid website: https://www.icpcovid.com/.

Conflicts of Interest: The authors declare no conflict of interest. The funders had no role in the design of the study; in the collection, analyses, or interpretation of data; in the writing of the manuscript, or in the decision to publish the results.

\section{References}

1. World Health Organisation. WHO Director-General's Opening Remarks at the Media brieFing on COVID-19-11 March 2020. Available online: https://www.who.int/dg/speeches/detail/who-director-general-s-opening-remarks-at-the-media-briefingon-covid-19---11-march-2020 (accessed on 21 October 2020).

2. World Health Organisation. Strengthening Preparedness for COVID-19 in Cities and Urban Settings. Available online: https: //www.who.int/publications/i/item/strengthening-preparedness-for-covid-19-in-cities-and-urban-settings (accessed on 21 October 2020).

3. Presidência da República. Decreto Presidencial nº 11/2020 de Março, Declara o Estado de Emergência, por Razões de Calamidade Pública, em todo o território nacional. Available online: https:/ /www.mic.gov.mz/por/covid-192/ (accessed on 21 October 2020).

4. Presidência da República; Decreto Presidencial no 79/2020 de 4 de Setembro de 2020. Available online: http:/ /www.ts.gov.mz/ images/Decreto_n._792020_de_4_de_Setembro_-_Declara_a_situac\%C3\%A3o_da_calamidade_P\%C3\%BAblica_e_Activa_o_ Alerta_Vermelho_compressed.pdfpdf (accessed on 21 October 2020).

5. Ministry of Health Mozambique. Boletím Diário 2020, No 2078, 11 October. Available online: https://covid19.ins.gov.mz/wpcontent/uploads/2020/10/Boletim-Diario-208.pdf (accessed on 21 October 2020).

6. National Insitute of Health Mozambique. Sero-Prevalence Survey Maputo City-Preliminary Results Presented on 31/08/2020. 2020. Available online: https://covid19.ins.gov.mz/wp-content/uploads/2020/08/Inque\%CC\%81rito-SE-SARS-CoV-2_Cidadede-Maputo_resultados_31Ago2020.pdf (accessed on 29 November 2020).

7. Siewe Fodjo, J.N.; Pengpid, S.; Villela, E.F.M.; Van Thang, V.; Ahmed, M.; Ditekemena, J.; Crespo, B.V.; Wanyenze, R.K.; Dula, J.; Watanabe, T.; et al. Mass masking as a way to contain COVID-19 and exit lockdown in low- and middle-income countries. J. Infect. 2020, 81, e1-e5. [CrossRef] [PubMed]

8. Ahmed, M.A.M.; Siewe Fodjo, J.N.; Gele, A.A.; Farah, A.A.; Osman, S.; Guled, I.A.; Ali, A.M.; Colebunders, R. COVID-19 in Somalia: Adherence to Preventive Measures and Evolution of the Disease Burden. Pathogens 2020, 9, 735. [CrossRef] [PubMed]

9. Ilesanmi, O.; Afolabi, A. Perception and practices during the COVID-19 pandemic in an urban community in Nigeria: A cross-sectional study. PeerJ 2020, 8, e10038. [CrossRef] [PubMed]

10. World Health Organisation. Public Health Surveillance for COVID-19: Interim Guidance. Available online: https://www.who. int/publications-detail-redirect/who-2019-nCoV-surveillanceguidance-2020.7 (accessed on 21 October 2020).

11. National Insitute of Health Mozambique. Sero-Prevalence Survey Tete Province-Preliminary Results Presented on 24 September 2020. Available online: https://covid19.ins.gov.mz/wp-content/uploads/2020/09/Inque\%CC\%81rito-SE-SARS-CoV-2_Cidadede-Tete_resultados.pdf (accessed on 29 November 2020). 
12. National Insitute of Health Mozambique. Sero-Prevalence Survey Nampula Province-Preliminary Results Presented on 1 July 2020. Available online: https://covid19.ins.gov.mz/wp-content/uploads/2020/08/Inquerito-SARS-CoV-2-PEMBA_ -RESULTADOS-PRELIMINARES_FINAL_2_27.07.2020.pdf (accessed on 29 November 2020).

13. Leung, N.H.L.; Chu, D.K.W.; Shiu, E.Y.C.; Chan, K.H.; McDevitt, J.J.; Hau, B.J.P.; Yen, H.L.; Li, Y.; Ip, D.K.M.; Peiris, J.S.M.; et al. Respiratory virus shedding in exhaled breath and efficacy of face masks. Nat. Med. 2020, 26, 676-680. [CrossRef] [PubMed]

14. Tso, R.V.; Cowling, B.J. Importance of face masks for COVID-19-A call for effective public education. Clin. Infect. Dis. 2020, 71, 2195-2198. [CrossRef] [PubMed] 